\title{
Evaluation of cadmium toxicity on the population growth of Brachionus plicatilis (O. F. Müller)
}

\author{
Chinnasamy Arulvasu ${ }^{1}$, Kumar Padmini $^{1}$, Perumal Prabu ${ }^{1}$, Nallamuthu Thangaraju ${ }^{2}$, \\ Devadoss Dinesh ${ }^{1}$ and Subramani Sellamuthu ${ }^{1}$ \\ ${ }^{1}$ Dept. of Zoology, ${ }^{2}$ Centre for Advanced Studies in Botany, University of Madras, Chennai-600 025, India. \\ carulvasu@gmail.com
}

\begin{abstract}
The effect of heavy metal (cadmium chloride) toxicity on the reproductive bionomics of the rotifer Brachionus plicatilis was assessed. Bioassay was performed to obtain sub-lethal concentration of cadmium chloride using different concentrations $(0.2,0.4,0.8,1.0$ and $1.2 \mathrm{mg} / \mathrm{l})$ and the $\mathrm{LC}_{50}$ value of $B$. plicatilis was identified as $0.8 \mathrm{mg} / \mathrm{l}$. Based on the $\mathrm{LC}_{50}$ value, newly hatched neonates were individually culture with five varying concentrations $(0.1,0.3,0.4,0.6$ and $0.7 \mathrm{mg} / \mathrm{l}$ ) of cadmium chloride. The life history parameters, such as time (hour) the rotifer released neonates and life span, were evaluated. These results showed that the population growth of $B$. plicatilis decreased with increasing concentrations of cadmium chloride.
\end{abstract}

Keywords. Cadmium chloride, life history parameter, heavy metal toxicity, rotifers, B. plicatilis.

Introduction

Human activities have always impacted coastal areas. In the last two centuries, the effects of industrialization, intensive agriculture and coastal engineering have seriously begun to threaten marine life (His et al., 1999). Most of these impacts have led to environmental pollution. Many substances pollute the marine environment, but non-biodegradable compounds are the most dangerous, due to their innate ability to constantly remain within the ecosystem (Hernandez-Hernandez et al., 1990). Thousands of aquatic systems are directly influenced by mining, metal smelting and other industrial activities and have been contaminated by potentially toxic trace metals such as cadmium, copper lead, etc., (Pacyna et al., 1995). Trace metals are also transported long distances in the atmosphere (Nriagu \& Pacyna, 1988), thereby reaching aquatic ecosystems distant from local sources (Fransin et al., 1979; Verta et al., 1986).

Heavy metals are non-biodegradable and can be accumulated by organisms to a level that affects their physiological states. Heavy metals adsorbed to (or accumulated by) algae pass to zooplankton via ingestion, causing reduced survival and reproduction of the latter (Barata et al., 2002). The net result of changes in zooplankton survival and reproduction can be quantified using population growth studies (Krebs, 1985), where individuals of various generations simultaneously occur over a large period of time (Gama-Flores et al., 1999). Cadmium also is an inevitable by-product of industrial production of zinc, lead and copper (Engel \& Fowler, 1979). After being applied, it enters the environment mainly through the ground, because it is used as in manures and pesticides. Aquatic organisms have been widely used as an indicator for environmental pollution because of their ecological and economic importance and their morphological, physiological and ecological diversity in aquatic habitats. Zooplankton, being the common component of aquatic ecosystems, is subjected to heavy metal toxicity (Monterio et al., 1995). The marine rotifer $B$. plicatilis is commonly used as a toxicity test species due to its cosmopolitan distribution, important trophic roles in the marine ecosystem (Wallace \& Snell, 1991; Nogrady et al., 1993), short generation time (about 24 hours), easy culture in small spaces (Fukusho K, 1983) and wide salinity adaptability (Komis A, 1992). Standard methods for toxicity testing using rotifers $(B$. plicatilis for marine and $B$. calyciflorus for freshwater) have been established (Snell \& Persoone, 1989; ASTM, 1996; Preston et al., 2000; Guerra, 2001; Preston \& Snell, 2001a, b). Although a volume of information is available on the impact of heavy metal toxicity in rotifers, not much work has been done on cadmium toxicity. Hence the present study attempts to evaluate the effect of cadmium chloride on the population growth of the euryhaline rotifer B. plicatilis.

\section{Materials and Methods \\ Collection and isolation of rotifers}

The rotifer $B$. plicatilis was used as experimental species. The samples were collected and isolated from Muttukadu backwaters near Chennai, Tamil Nadu, India. Samples were collected using $20 \mu \mathrm{m}$ mesh nets and filtered through $50 \mu \mathrm{m}$ and $200 \mu \mathrm{m}$ mesh-size filters. The collected rotifers were isolated and viewed under stereomicroscope (Leica DM2500 Trinocular Phase Contrast Microscope with DIC, Leica Microsystems Wetzlar $\mathrm{GmbH}$, Germany). Brackish water brachionid rotifers were identified as per the description of Ruttner-Kolisko (1974).
Research article

CIndian Society for Education and Environment (iSee)
"Cadmium toxicity on Brachionus plicatilis " http://www.indjst.org
Arulvasu et al. Indian J.Sci.Technol. 


\section{Culture of algae and rotifer}

Marine Chlorella vulgaris was cultured under laboratory conditions with the optimum temperature of about $25^{\circ} \mathrm{C}$ and $\mathrm{pH} 7.9$ in a normal $\mathrm{f} / 2$ medium. The isolated $B$. plicatilis were fed with $C$. vulgaris at a density $2 \times 10^{6} \mathrm{cells} / \mathrm{ml}$ and the $\mathrm{pH}$ was maintained at $6.5 \pm 0.5$. The experimental temperature for the culture of rotifers is $25^{\circ} \mathrm{C}$ and the salinity was held at $30 \%$ (Hirayam \& Kusano, 1972).

Fig. 1. The population growth of Brachionus plicatilis treated with cadmium chloride at various concentrations ( $\mathrm{mg} / \mathrm{l})$. Each point represents the mean \pm S.D. of 3 independent experiments $(P<0.05)$.

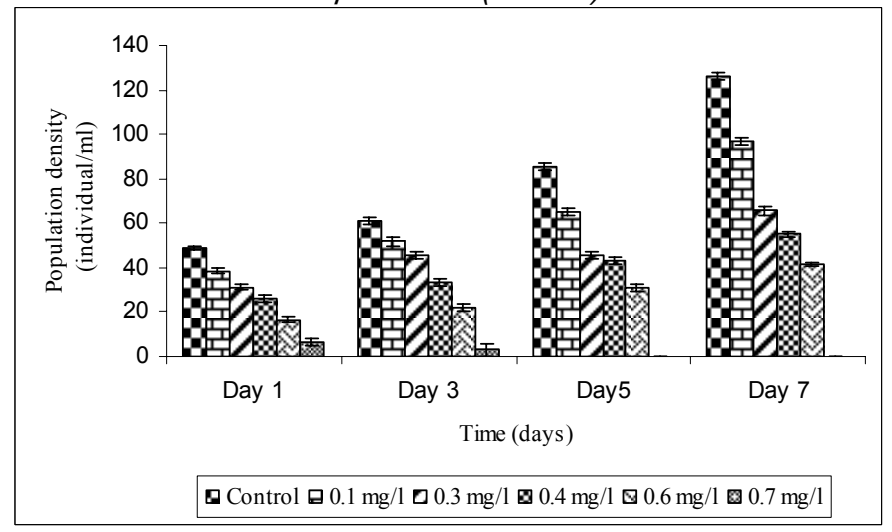

Acute toxicity test

Heavy metal Cadmium chloride (technical grade) was used for toxicant in this study. A stock solution of cadmium chloride was prepared at $1000 \mathrm{mg} / \mathrm{l}$ in distilled water (Sarma et al., 2001a). For acute toxicity tests, five different concentrations of cadmium chloride $(0.2,0.4$, $0.8,1.0$ and $1.2 \mathrm{mg} / \mathrm{l}$ ) were selected from the serial dilutions of stock solutions in addition to controls (without toxicant). Three replicates were used for each concentration, using $20 \mathrm{ml}$ medium containing 50 adults of $B$. plicatilis. After $24 \pm 2$ hours, the number of rotifers alive in each test container was counted. LC $_{50}$ values were derived by the prohibit method of Finney (1971).

Experimental procedure

Based on $\mathrm{LC}_{50}$ values, the population growth studies were subjected to various concentrations of toxicant such as, $0.1,0.3,0.4,0.6$ and $0.7 \mathrm{mg} / \mathrm{l}$. The population growth experiments were conducted in $50 \mathrm{ml}$ beakers with $20 \mathrm{ml}$ of filtered sea water and 5 rotifers $/ \mathrm{ml}$ and fed with C. vulgaris at a density $2 \times 10^{6} \mathrm{cells} / \mathrm{ml}$. After inoculation, every alternate day the number of live rotifers were estimated using two or three aliquots of $0.5-5 \mathrm{ml}$ each. The culture medium was renewed on alternate days with appropriate toxicant and the same algal densities noted above. The experiments were terminated after 7 days when most test populations began to decline. From the data, the rate of population growth was calculated using the following exponential equation. $R=\left(I_{n} N_{t}-I_{n} N_{o}\right) t$, where $N_{o}$ and $N_{t}$ are the initial and final population densities respectively and ' $\mathrm{t}$ ' is time in days.
Vol. 3 No. 1 (Jan 2010)

ISSN: 0974- 6846

\section{Chronic toxicity tests}

Chronic toxicity tests were performed to study the prolonged toxic effect of cadmium chloride on B. plicatilis. In these tests, the time taken for the development of embryos to neonates is measured. The embryos were separated by vigorous vortex mixing for $10-15$ minutes. The test tubes were then left to stand for 10 minutes to allow the separated embryos to settle. The embryos were removed with a pipette and then placed in an embryological watch glass according to the standard method of Toledo and Hisashi (1990). The embryos were separated and put into 24-well polysterene culture plates, with 50 embryos each. Each well-plate contained a $1 \mathrm{ml}$ mixture of embryos and the concentration of cadmium chloride varied in each plate. Then the time was noted up to the hatching of neonates from the embryo and till the formation of adult.

Statistical analysis

The 24 hour $\mathrm{LC}_{50}$ was calculated using probit analysis. Data on the population growth rates were subjected to one-way analysis of variance (ANOVA) using standard statistical methods (Sokal \& Rohlf, 2000).

Fig.2. Time interval of hatching of embryos to neonates in

B. plicatilis exposed to cadmium chloride at various concentrations. Each point represents the mean \pm S.D. of 3 independent experiments $(P<0.05)$.

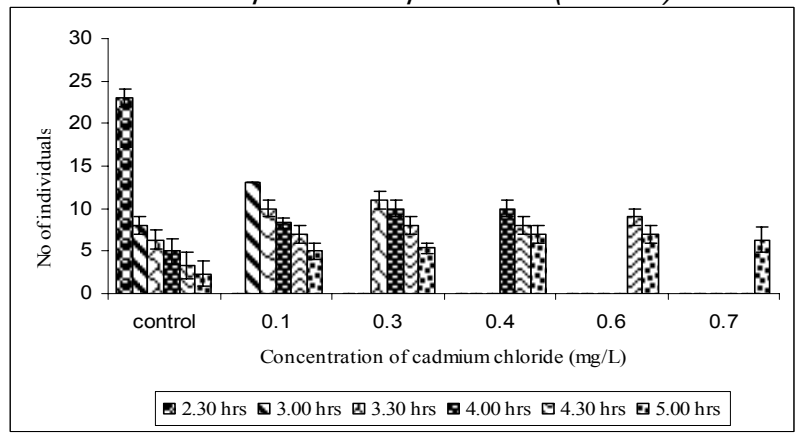

\section{Results}

The results from the 24 hour acute toxicity tests showed that cadmium chloride was highly toxic and the $\mathrm{LC}_{50}$ value of rotifer was $0.8 \mathrm{mg} / \mathrm{l}$. Population growth studies revealed a significant effect of cadmium chloride concentration on the maximum abundance of rotifers. The population growth obtained with various concentrations of cadmium chloride for the period of 7 days is given in Fig.1. Maximum abundance (rate of population increase) of rotifers was observed on day 7.

The population growth of $96.66 \pm 1.52$ individuals were obtained for $0.1 \mathrm{mg} / \mathrm{l}$ concentration and $41.66 \pm 1.52$ was recorded at $0.6 \mathrm{mg} / \mathrm{l}$ concentration for the period of $7^{\text {th }}$ day. The $0.7 \mathrm{mg} / \mathrm{l}$ concentration shows no survival from the $5^{\text {th }}$ day onwards. The results showed that the decreased population growth was seen with increasing concentration of cadmium chloride.

The results from the chronic toxicity tests showed that hatching rate of eggs exposed to cadmium chloride is the
Research article

CIndian Society for Education and Environment (iSee)
"Cadmium toxicity on Brachionus plicatilis " http://www.indjst.org
Arulvasu et al. Indian J.Sci.Technol. 
most sensitive end point. The embryos were exposed to cadmium chloride at the concentration of $0.1-0.7 \mathrm{mg} / \mathrm{l}$, and the time taken for hatching of embryo to neonate was assessed. The hatchability period was varied from 2.30 hours to 5.00 hours. The hatching of embryos was recorded only in $5^{\text {th }}$ hour at $0.7 \mathrm{mg} / \mathrm{l}$ cadmium chloride for exposed groups. For the control, the maximum level of hatching showed 2.30 hours of incubation, when compared to embryo exposed with different concentrations of cadmium chloride (Fig. 2).

The time taken for the formation of adults from neonates varied form 6 to 16 hours. The maximum number of adults was at $0.1 \mathrm{mg} / \mathrm{l}$ concentration of cadmium chloride for exposed group when compared with control groups (Fig. 3).

Fig.3. Time interval of neonates to adult B. plicatilis exposed to cadmium chloride at various concentrations. Each point represents the mean $\pm S$.D. of 3 independent experiments $(P<0.05)$.

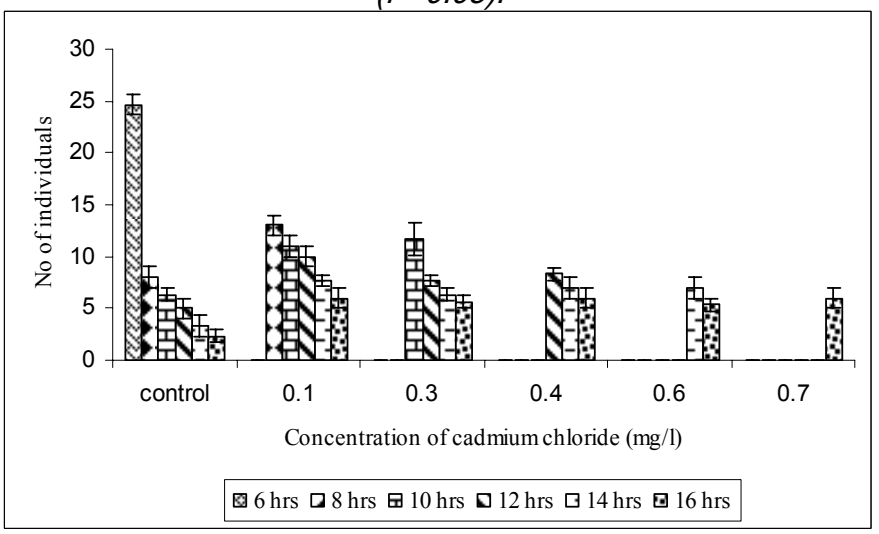

\section{Discussion}

In general the environmental impact of heavy metals varied greatly. The evaluation of heavy metal toxicity to zooplankton is gaining importance for several reasons. Zooplankton species are sensitive to metal pollution, large numbers of test individuals can be employed in relatively smaller volumes, and evaluations can be done rapidly (Sarma \& Nandhini, 2001). In the present investigation, the effect of cadmium toxicity on $B$. plicatilis was studied with various appropriate parameters. The few studies of cadmium toxicity have been largely performed on fish (Pickering \& Henderson, 1966; Ball, 1976; Eisler, 1971; Pickering \& Gast, 1972).

Population growth studies are important aspects, largely used to evaluate toxicant effects of heavy metals and pesticides to zooplankton (Nogrady et al., 1993). The fact that toxicants reduce the duration of lifespan of zooplankton has been largely documented in many species, for example rotifers (Ferrando et al., 1999) and cladocerans. In the present study, the population growth of $B$. plicatilis in relation to different concentrations of cadmium chloride $(0.1-0.7 \mathrm{mg} / \mathrm{l})$ showed that the population growth decreased with increasing concentrations of heavy metal. This observation was
Vol. 3 No. 1 (Jan 2010)

ISSN: 0974- 6846 comparable to the findings of Rios-Arana et al. (2007) on rotifer Plationus patulus. Similarly, Sarma et al. (2001a) explained that increases in the toxicant concentration had a strong negative effect on the population growth of B. rubens. According to Ramirez-perez et al. (2004), when the mercury concentration in the medium was enhanced from 0 to $0.005 \mathrm{mg} / \mathrm{l}$, there was a considerable reduction in both average lifespan and life expectancy of B. calyciflorus.

In conclusion the rotifer $B$. plicatilis showed decreases in population with increasing cadmium concentrations. As the above results indicated, this study is suitable for showing the ecological effects of cadmium on the rotifer $B$. plicatilis in brackish water bodies.

\section{References}

1. ASTM (1996) Standard guide for acute toxicity test with the rotifer Brachionus. E1440-1449.

2. Ball IR (1967) The toxicity of cadmium to rainbow trout (Salmo gairdneri Richardson). Water Res. 1, 805-806.

3. Barata C, Baird DJ and Soares AMVM (2002) Demographic responses of a tropical cladoceran to cadmium: effects of food supply and density. Ecol. App. 12, 552-564.

4. Eisler R (1971) Cadmium poisoning in Fundulus heteroclitus (Pisces: Cyrinodontidae) and other marine organisms. J. Fish. Res. Board Can. 28, 1225-1234.

5. Engel DW and Fowler BA (1979) Factors influencing cadmium accumulation and its toxicity to marine organisms. Env. Health Perspectives. 28, 81-88.

6. Ferrando $M D$, Sancho $E$ and Andrue-Moliner $E$ (1996) Chronic toxicity of fenitrothion to an algae (Nannochloris oculata), a rotifer (Brachionus calyciflorus) and the cladoceran (Daphinamagena). Ecotoxicolo. Envi. Safety. 35,112-120.

7. Ferrando MD, Sancho E, Villarroel MJ, Sanchez M and Andreu E (1999) Comparative toxicity of two herbicides, molinate and thiobencarb, to Brachionus calyciflorus. J. Envi. Sci. Health Part-B pesticides Food Contamination Agri. Wastes. 34, 569-586.

8. Finney DJ (1971) Probit analysis. $3^{\text {rd }}$ edn. Cambridge University Press, London.

9. Fransin WG, Mc Farlane GA and Lutz A (1979) Atmospheric fallout in the vicinity of a base metal smelter at Flin Flon, Manitoba, Canada. Envi. Sci. Tech. 13, 1513-1522.

10. Fukusho K (1983) Present status and problems in culture of the rotifer Brachionus plicatilis for fry production of marine fishes in Japan. In: Advances and Perspectives in Aquaculture. Proc. Sym. (ed) Fuentes HR, Castillo JG \& Disalvo LH, Universidad del Norte, Coquimbo, Chile.

11. Gama-Flores JL, Sarma SSS and Arazia MAF (1999) Combined effects of Chlorella density and methyl parathion concentration on the population growth of
Research article

CIndian Society for Education and Environment (iSee)
"Cadmium toxicity on Brachionus plicatilis " http://www.indjst.org
Arulvasu et al. Indian J.Sci.Technol. 
Brachionus calyciflorus (Rotifera). Bull. Envi. Contamin. Toxicol. 62, 769-755.

12. Guerra R (2001) Ecotoxicological and chemical evaluation of phenolic compounds in industrial effluents. Chemosphere. 44, 1737-1747.

13. Hernandez-Hernandez F, Medina J, Ansuategui J and Conesa M (1990) Heavy metal concentrations in some marine organisms from the Mediterranean Sea (Castellon, Spain); Metal accumulation in different tissues. Scientia Marina. 54(2), 113-129.

14. Hirayam K and Kusano $T$ (1972) Fundamental studies on physiology of rotifer foe its mass culture. II influence of water temperature on population growth rotifer. Bull. Jap. Soci. Scientific Fisheries. 38, 13571363.

15. His E, Beiras R and Seaman MNL (1999) The assessment of marine pollution- bioassays with bivalve embryos and larvae. Adv. Marine Biol. 371178.

16. Komis A (1992) Improved production and utilization of the rotifer Brachionus plicatilis Muller in European sea bream (Sparus auratus Linnaeus) and sea bass (Dicentrarchus labrax Linnaeus) larviculture. Univ. of Ghent, Belgium.

17. Krebs CJ (1985) Ecology: The Experimental Analysis of Distribution and Abundance, $3^{\text {rd }}$ edn. Harper and Row, pp:1-382.

18. Monterio MT, Oliveira R, Vale C (1995) Metal stress on the plankton communities of Sado River (Portugal). Water Res. 29, 695-701.

19. Nogrady T, Wallace RI and Snell TW (1993) Rotifera. In: Biology, ecology and systematics. Vol. I., SPB Academica Publi., Hague, Netherlands.

20. Nriagu JO and Pacyna JM (1988) Quantitative assessment of world wide contamination of air, water and soils by trace metals. Nature. 333, 134-139.

21. Pacyna JM, Scholtz MT and Li YF (1995) Global budget of trace metal sources. Envi. Rev. 3, 145-159.

22. Pickering QH and Gast MH (1972) Acute and chronic toxicity of cadmium to the flathead minnow (Pimephales promelas). J. Fish. Res. Board of Canada. 29, 1099-1106.

23. Pickering QH and Henderson C (1966) The acute toxicity of some heavy metals to different species of warm water fishes. Inter. J. Air. Water Poll. 10, 45363.

24. Preston BL and Snell TW (2001a) Full life cycle toxicity assessment using rotifer resting egg production, Implications for ecological risk assessment. Envi.I Pol. 114, 399-406.

25. Preston BL and Snell TW (2001b) Direct and indirect effects of sublethal toxicant exposure on population dynamics of freshwater rotifers. A modeling approach. Aquatic Toxicol. 52, 87-90.

26. Preston BL, Snell TW, Robertson TL and Dingmann BJ (2000) Use of freshwater rotifer Brachionus
Vol. 3 No. 1 (Jan 2010)

ISSN: 0974- 6846

calyciflorus in screening assay for potential endocrine disrupters. Envi. Toxicol. Chem. 19, 2923-2928.

27. Ramirez-perez T, Sarma SSS and Nandini S (2004) Effects of Mercury on the life table demography of the rotifer Brachionus calyciflorus Pallas (Rotifera). Ecototoxic.13, 535-544.

28. Rios-Arana, Judith $\mathrm{V}$, Walsh, Elizabeth $\mathrm{J}$ and Melchor Ortiz (2007) Interaction effects of multi-metal solutions (As, $\mathrm{Cr}, \mathrm{Cu}, \mathrm{Ni}, \mathrm{Pb}$ and $\mathrm{Zn}$ ) on life history traits in the rotifer Plationus patulus. J. Envi. Sci. Health Part A. 42, 1473-1481.

29. Ruttner-Koliski A (1974) Plankton rotifers, biology and taxonomy. In: Elstter HJ \& Ohle W (Eds), Die Binnengewasser. E. Schweizer-bart'sche Velagsbuchhandlung. pp:146.

30. Sarma SSS and Nandhini S (2001) Life table demography and population growth of Brachionus variabilis Hampel, 1896 in relation to algal (Chlorella vulgaris) density. Hydrobiologia. 446/447, 75-83.

31. Sarma SSS, Nandini S and Ramirez-Perez T (2001a) Combined effects of mercury and algal food density on the population dynamics of Brachionus patulus (Rotifera). J. Fish. Res. Board of Canada. 67, 841-7.

32. Snell TW and Persoone G (1989) Acute toxicity bioassays using rotifers, I. A test for brackish and marine environments with Brachionus plicatilis. Aqua. Toxicol. 14, 65-80.

33. Sokal RR and Rohlf FJ (2000) Biometry, W.H. Freeman and company, San Francisco.

34. Toledo JD and Hisashi K (1990) Cryopreservation of the euryhaline rotifer Brachionus plicatilis embryos. Aquaculture. 91, 385-394.

35. Verta M, Rekolainen S, Mannio J and Surma-Aho K (1986) The origin of level of mercury in Finnish forest lakes. Public. of the Water Res. Inst, National Board Waters, Helsinki, Finland. 65, 21-31.

36. Wallace RL and Snell TW (1991) Rotifer. In: Thorp $\mathrm{JH}$, Covich Ap, (eds.), Ecology and Classification of North American Freshwater Invertebrates. Academic, NY, USA. pp: 187-248.
Research article

CIndian Society for Education and Environment (iSee)
"Cadmium toxicity on Brachionus plicatilis " http://www.indjst.org
Arulvasu et al. Indian J.Sci.Technol. 